\title{
Study of Inventory Management of Raw Material Using Wagner-Within Algorithm
}

\author{
Defi Norita \\ Department of Industrial Engineering, \\ Faculty of Engineering, University Mercu Buana \\ Indonesia
}

\begin{abstract}
The rapid development of science and technology is increasingly sophisticated, making every company should have a business strategy while upholding the quality of the product and optimize all its resources in accordance with the development of ABC global PT era is a company engaged in the pharmaceutical industry, specifically customer health products. Argon gas availability VGL becomes important to support the activities of laboratory testing. Inventory planning is needed so that appropriate testing needs by calculating safety stock and delivery lead time. This study uses the Wagner-Within algorithm calculation and also estimation of total costs.

This method was chosen as the optimum method to solve the problems of argon gas inventory VGL deterministic dynamic. This method is used to determine the amount of argon gas stocks are bought and stored VGL right, at the right time, and frequency of ordering, as well as the total cost of inventory. In this study, the calculation of total variable costs, the total minimum cost, and lays out the lot size and calculate the total cost of inventory Algorithms Wagner-Within and Economic Order Quantity. The total cost of inventory Wagner-Within algorithm for Rp691.500.000. This cost is obtained from the calculation of the total cost per period based upon the lot size and the time of reservation obtained from the Wagner-Within algorithm calculation, while the total cost of inventory EOQ Rp.694.875 million.
\end{abstract}

Key Words: Inventory, Deterministic Models, Algorithms Wagner-Within.

\section{INTRODUCTION}

PT ABC is one of the global companies in the pharmaceutical industry, health customer exactly which consists of several departments, one of which is Quality Control.Quality Control Department has a few routine tests performed on each product. One such routine testing is the mineral content. Testing levels of minerals become one of the parameters required for each product supplement.

Testing levels of minerals in supplements is done using an instrument such as ICP-OES (Inductively Coupled Plasma-Optical Emission Spectrometry). The minerals contained in supplements generally are Calcium, Magnesium, Zinc, Phosphorus, Manganese, Selenium, Iron and Copper. To perform such tests, can not be separated from the use of chemicals and argon gas as a carrier gas in each of the measurement process with ICP-OES instrumentation is. Availability of chemicals and gases Argon VGL becomes important to support such activities. Companies must be able to regulate the management of inventory to support the event. Inventory planning is needed so that appropriate testing needs by calculating safety stock and delivery lead time.

Several previous studies include Hamida and Maria (2015) in his research entitled Analysis of Product Inventory Control Inventory To Minimize Costs With Wagner-Within algorithm, shows that using Wagner-Within algorithm obtained optimum inventory control strategy in 2013 is to calculate the total cost of iteration then defines the minimum costs that occurred during this period and translating the optimum solutions in tire production. Another study conducted by Basuki (2016), with the title of Booking Lot Size Optimization Economical on Algorithm Using Dynamic Deterministic Demand Wagner-Within, showing that the method Algorithm Wagner-Within one optimization solution to solve inventory problems are deterministic dynamic. To get a booking economical lot size always pay attention to the cost of inventory will be used as criteria for the performance of the inventory system.

In addition, the research conducted Adelia Chandradevi and Nia Budi Puspitasari (2016), entitled Application of Material Requirement Planning (MRP) with Consider Lot Sizing in Control of Raw Materials in PT Phapros, Tbk showed that the method Algorithm Wagner-Within able to minimize the total cost of the must be issued by the company. 


\subsection{Formulation of the problem}

Based on the background described above, the problems are the focus of this study is

1. How Argon Gas inventory control VGL optimal quality control laboratory PT ABC?

2. What is the total cost of inventory using Wagner-Within algorithm?

\section{RESEARCH PURPOSES}

This study has several objectives, including:

1. Argon gas determines the amount of stock purchased and stored VGL right, at the right time, and the frequency of booking.

2. Determining the total cost of inventory

\subsection{Limitations of the study}

In the making of this study, limited by several things, including:

1. The study was conducted in laboratory quality control PT. A B C

2. In this study, the data will be used is booking data and the use of Argon Gas VGL from January 2018 until December 2018 in the laboratory quality control PT ABC.

3. Inventory control method is the method of Wagner-Within algorithm.

\section{LITERATURE REVIEW}

\subsection{Stock}

Supplies are a major part of the working capital, the assets at any time subject to change. (Gitosudarmo, 2002). Accuracy in anticipating supply needs to be done so that each customer demand can be met. Total Cost of Inventory is the total cost caused by inventories, useful to compare current inventory policy with the new policy. According to the Senator (2006), the formula for calculation of total inventory costs (OT) is as follows:

OT $=+$ Booking Fee Subscription Fee + Cost of Storage

$=(\mathrm{D} p)+()+() x \frac{A D}{q_{0}} \frac{1}{2} q_{0} x h$

Where :

D $\quad=$ The number of items purchased

$\mathrm{p} \quad=$ Price of goods per unit was

A $\quad=$ The booking fee

q0 = Lot Size reservations

$\mathrm{h}=$ Cost of Storage

\subsection{Economic Order Quantity (EOQ)}

Freddy Rangkuti (2004) states that the EOQ method is the method used to determine the amount of the purchase of raw materials at any time a message with the lowest cost. Some basic assumptions to use EOQ method are:

1. Requests can be determined exactly and constant sehingg and stock out costs related to the capacity does not exist.

2. The items were booked independently with other items.

3. Reservations are accepted with immediate and certain.

4. The item price is constant.

The formula used to calculate the EOQ is as follows.

$\mathrm{EOQ}=\sqrt{\frac{2 D S}{H}}$

Where:

EOQ = Number of units per order

$\mathrm{D} \quad=$ Annual Needs

$\mathrm{S} \quad=$ The booking fee per order

$\mathrm{H} \quad=$ Cost per unit of storage 


\subsection{Wagner-Within algorithm}

According Tersine (1994) Wagner Within Algorithm Method is a method that can provide optimal value for lot sizing problems which are dynamic in accordance with the horizon period. This method uses dynamic programming approach to find the optimal solution. Steps to Wagner Within Algorithm with tread models of limitations warehouse capacity:

1. Calculate and check the limits on Qce when the booking is made in the period c to meet the demand of the period $\mathrm{c}$ through $\mathrm{e}$ period should not exceed the capacity of the warehouse.

\section{$\leq$ Qcewarehouse capacity}

2. Calculate the total matrix variable costs (cost of the message and save costs) for the entire alternative bookings throughout the planning horizon consisting of $\mathrm{N}$ period (the result of the first step). ZCE is defined as the total variable costs (from period to period $\mathrm{c}$ e) when a reservation is made in the period $\mathrm{c}$ to meet the demand period to period $\mathrm{c}$ e. ZCE The formulation is as follows:

$$
Z c e=\mathrm{C}+\mathrm{h}) \text { for } 1 \leq \mathrm{c} \leq \mathrm{e} \leq \mathrm{N} \sum_{i=c}^{e}\left(Q_{c e}-Q_{c i}\right.
$$

Information :

$\mathrm{C}=$ Cost of message

$\mathrm{h}=$ Cost savings per unit per period

$$
Q_{c e}=\sum_{k=c}^{e} D_{k}
$$

Information :

$\mathrm{Dk}=$ Demand per period $\mathrm{k}$

3. Fe is defined as the minimum possible cost in the period 1 to period e assuming inventory levels at the end of the period e is zero. The algorithm starts with $\mathrm{f} 0=0$ and start counting sequentially $\mathrm{f} 1, \mathrm{f} 2, \ldots, \mathrm{fn}$. FN value is the value of the cost of the optimal order.

$$
f e=\operatorname{Min}\{Z c e+f c-1\} \text { for } \mathrm{c}=1,2, \ldots, \mathrm{e}
$$

4. Interpret fn be the lot size in the following manner:

a. Last booking made during the period $w$ to meet the demand from period to period N. $w$

$$
f n=Z w N+f w-1
$$

b. Booking before final booking should be done in the period of $\mathrm{v}$ to meet the demand of period to period $\mathrm{w} v-1$.

$$
F w-1=Z v w-1+f v-1
$$

c. Booking must first be conducted from 1 to meet the demand from period 1 to period $\mathrm{u}-1$

$$
f u-1=Z 1 u-1+f O
$$

\section{RESEARCH METHODS}

\subsection{Method of collecting data}

Data collection methods used in the preparation of this study are as follows:

\section{Study of literature}

Searching reference theories relevant to the case or the problems found containing data relating to the topics raised in the study. The study of literature is obtained from various sources, both in the form of journals, books, internet, or guide of pharmacopoeia as a basic reference in Pharma companies.

\section{Observation}

Conducting a series of direct observation of the object of the problem and then collect data though the observations and data. Interviews were conducted to obtain data on Argon gas purchase data VGL.

\section{Documentation}

Finding documents or data on companies that are considered important for applied research. The document related to the cost of foregone fees associated with good VGL Argon gas usage, as well as other treatments. 


\subsection{Processing Methods and Data Analysis}

Data processing methods used by the author is using the Wagner-Within algorithm and Economic Order Quantity

\subsection{DATA COLLECTION AND PROCESSING}

Estimates reservations VGL argon gas during the year 2018 in January and December can be seen in Table 1.

Table 1. Estimates of argon gas reservation VGL

\begin{tabular}{|c|c|c|}
\hline $\begin{array}{c}\text { Period (Months } \\
\text { to) }\end{array}$ & $\begin{array}{c}\text { Demand } \\
\text { (Tube) }\end{array}$ & Cumulative \\
\hline 1 & 6 & 6 \\
\hline 2 & 6 & 12 \\
\hline 3 & 8 & 20 \\
\hline 4 & 5 & 25 \\
\hline 5 & 7 & 32 \\
\hline 6 & 6 & 38 \\
\hline 7 & 7 & 45 \\
\hline 8 & 8 & 53 \\
\hline 9 & 7 & 60 \\
\hline 10 & 6 & 66 \\
\hline 11 & 7 & 73 \\
\hline 12 & 8 & 81 \\
\hline
\end{tabular}

1. The first step Wagner-Within the calculation algorithm is to calculate the total variable costs, which include fees and the cost of alternative storage for all inventory for 12 planning period in 2018.

The cost of inventories $\left.\left(\mathrm{Z}_{\mathrm{ce}}\right)=\mathrm{C}+\mathrm{h}\right)$ for $1 \leq \mathrm{c} \leq \mathrm{e} \leq \mathrm{N} \sum_{i=c}^{e}\left(Q_{c e}-Q_{c i}\right.$

$$
\begin{aligned}
Z_{1.1} & =250,000+1,000,000(6-6) \\
& =250,000 \\
Z_{1.2} & =250,000+1,000,000[(12-6)+(12-12)] \\
& =6,250,000
\end{aligned}
$$

2. The second step Wagner-Within algorithm calculation is defining the possibility of a minimum cost $\left(f_{n}\right)$ inventory levels. Value $\mathrm{f} 0=0$, then calculate in sequence to get the value of $\mathrm{f} 12$ using the following formula:

$$
\begin{aligned}
f e & =\operatorname{Min}\left\{Z_{c e}+f c-1\right\} \text { for } \mathrm{c}=1,2, \ldots, \mathrm{e} \\
f_{0} & =0 \\
f_{1} & =\operatorname{Min}\left[\mathrm{Z}_{1.1}+\mathrm{f} 1-1\right] \\
& =\operatorname{Min}[250+0] \\
& =250 \text { to } \mathrm{Z}_{1.1}+\mathrm{f}_{0} \\
f_{2} & =\operatorname{Min}\left[\left(\mathrm{Z}_{1.2}+\mathrm{f}_{0}\right) ;\left[\left(\mathrm{Z}_{2.2}+\mathrm{f}_{1}\right)\right]\right. \\
& =\operatorname{Min}[(6250+0) ;(250+250)] \\
& =500 \text { to } \mathrm{Z}_{2.2}+\mathrm{f}_{1}
\end{aligned}
$$

3. The third step Wagner-Within the calculation algorithm is to describe the minimum cost $\left(\mathrm{f}_{\mathrm{n}}\right)$ be a lot size of the booking and ordering period, then obtained the following results:

- $f_{12}=\mathrm{Z}_{12.12}+\mathrm{f}_{11}$, mean that the lot size of 8 tubes bookings made during the period 12 to meet demand in the period 12 .

- $f_{11}=\mathrm{Z}_{11.11}+\mathrm{f}_{10}$, mean that the lot size by 7 tube bookings made during the period 11 to meet demand in the period 11 .

- $f_{10}=\mathrm{Z}_{10.10}+\mathrm{f}_{9}$, mean that the lot size of 6 tubes reservations made in the period 10 to meet demand in the period 10 .

- $f_{9}=\mathrm{Z}_{9.9}+\mathrm{f}_{8}$, mean that the lot size by 7 tube reservations made in the period 9 to meet demand in the period 9 .

- $f_{8}=\mathrm{Z}_{8.8}+\mathrm{f}_{7}$, mean that the lot size of 8 tubes reservations made in the period from 8 to meet demand in the period 8 .

- $f_{7}=\mathrm{Z}_{7.7}+\mathrm{f}_{6}$, mean that the lot size by 7 tube reservations made in the period 7 to meet the demand in the period 7 .

- $f_{6}=\mathrm{Z}_{6.6}+\mathrm{f}_{5}$, mean that the lot size of 6 tubes reservations made in the period of 6 to meet demand in the period 6 .

- $f_{5}=Z_{5.5}+f_{4}$, mean that the lot size by 7 tube reservations made in the period 5 to meet the demand in the period 5 .

- $f_{4}=\mathrm{Z}_{4.4}+\mathrm{f}_{3}$, mean that the lot size of 5 tubes reservations made in the period of 4 to meet the demand in the fourth period.

- $f_{3}=Z_{3.3}+f_{2}$, mean that the lot size of 8 tubes reservations made in the period of 3 to meet the demand in the third period. 
- $f_{2}=\mathrm{Z}_{2.2}+\mathrm{f}_{1}$, meaning that the lot size of 6 tubes reservations made in the period 2 to meet the demand in the second period.

- $f_{1}=\mathrm{Z}_{1.1}+\mathrm{f}_{0}$, mean that the lot size of 6 tubes reservations made in the period 1 to meet the demand in period 1 .

Having in mind the size of the lot and the booking period is right, then the next calculation of the total cost of inventory in the period, with the following formula:

$\mathrm{OT}=($ Total Items $\mathrm{x}$ Price of goods $)+$ Booking fee + Cost of Storage

Based on the above calculation, the total cost of inventory in Wagner-Within algorithm can be seen in Table 2.

Table 2. Total Cost of inventories in Algorithm Wagner-Within

\begin{tabular}{|c|c|c|c|}
\hline Period & $\begin{array}{c}\text { Demand } \\
\text { (Tube) }\end{array}$ & $\begin{array}{c}\text { Procurement } \\
\text { (Tube) }\end{array}$ & Total Cost (USD) \\
\hline 1 & 6 & 6 & 51.25 million \\
\hline 2 & 6 & 6 & 51.25 million \\
\hline 3 & 8 & 8 & 68.25 million \\
\hline 4 & 5 & 5 & 42.75 million \\
\hline 5 & 7 & 7 & 59.75 million \\
\hline 6 & 6 & 6 & 51.25 million \\
\hline 7 & 7 & 7 & 59.75 million \\
\hline 8 & 8 & 8 & 68.25 million \\
\hline 9 & 7 & 7 & 59.75 million \\
\hline 10 & 6 & 6 & 51.25 million \\
\hline 11 & 7 & 7 & 59.75 million \\
\hline 12 & 8 & 8 & 68.25 million \\
\hline \multicolumn{2}{|r|}{ Total Cost of Inventory } & 691.5 million \\
\hline
\end{tabular}

\section{RESULTS AND DISCUSSION}

\subsection{Argon Gas reservations VGL}

Based on Table 1, it can be seen that the reservation VGL Argon gas during January 2018 until December 2018 were erratic in every month, it can happen because of the intensity of the use of ICP-OES instrumentation that is not the same every day depending on the number of samples.

Based on the calculation of the total cost of the variable data processing in the first step Wagner-Within algorithm method for 12 periods in Annex 1, where the total cost of this variable is obtained from the sum of the booking fee to the cost of storage per unit per period. Calculation of the total cost of this was done to find alternative bookings during the planning of 12 periods.

Appendix 1. Total Value Calculation Table Variable Cost USD (.000)

\begin{tabular}{|c|c|c|c|c|c|c|c|c|c|c|c|c|c|}
\hline \multicolumn{14}{|c|}{ Demand } \\
\hline \multirow{8}{*}{$\begin{array}{l}\text { 离 } \\
\text { 晋 } \\
\text { 豆 }\end{array}$} & & 1 & 2 & 3 & 4 & 5 & 6 & 7 & 8 & 9 & 10 & 11 & 12 \\
\hline & 1 & $\begin{array}{l}25 \\
0\end{array}$ & 625 & $\begin{array}{l}2225 \\
0\end{array}$ & $\begin{array}{l}3725 \\
0\end{array}$ & 6525 & 9525 & 13725 & 19325 & 24925 & 30325 & 37325 & $\begin{array}{l}46125 \\
0\end{array}$ \\
\hline & 2 & & 250 & 8250 & $\begin{array}{l}1825 \\
0\end{array}$ & $\begin{array}{l}3925 \\
0\end{array}$ & $\begin{array}{l}6325 \\
0\end{array}$ & 98250 & $\begin{array}{l}14625 \\
0\end{array}$ & $\begin{array}{l}19525 \\
0\end{array}$ & $\begin{array}{l}24325 \\
0\end{array}$ & $\begin{array}{l}30625 \\
0\end{array}$ & $\begin{array}{l}38625 \\
0\end{array}$ \\
\hline & 3 & & & 250 & 5250 & $\begin{array}{l}1925 \\
0\end{array}$ & $\begin{array}{l}3725 \\
0\end{array}$ & 65250 & $\begin{array}{l}10525 \\
0\end{array}$ & $\begin{array}{l}14725 \\
0\end{array}$ & $\begin{array}{l}18925 \\
0\end{array}$ & $\begin{array}{l}24525 \\
0\end{array}$ & $\begin{array}{l}31725 \\
0\end{array}$ \\
\hline & 4 & & & & 250 & 7250 & $\begin{array}{l}1925 \\
0\end{array}$ & 40250 & 72250 & $\begin{array}{l}10725 \\
0\end{array}$ & $\begin{array}{l}14325 \\
0\end{array}$ & $\begin{array}{l}19225 \\
0\end{array}$ & $\begin{array}{l}25625 \\
0\end{array}$ \\
\hline & 5 & & & & & 250 & 6250 & 20250 & 44250 & 72250 & $\begin{array}{l}10225 \\
0\end{array}$ & $\begin{array}{l}14425 \\
0\end{array}$ & $\begin{array}{l}20025 \\
0\end{array}$ \\
\hline & 6 & & & & & & 250 & 7250 & 23250 & 44250 & 68250 & $\begin{array}{l}10325 \\
0\end{array}$ & $\begin{array}{l}15125 \\
0\end{array}$ \\
\hline & 7 & & & & & & & 250 & 8250 & 22250 & 40250 & 68250 & $\begin{array}{l}10825 \\
0\end{array}$ \\
\hline
\end{tabular}


International Journal of Engineering Research and Advanced Technology, Vol. 8, No2, February -2022

\begin{tabular}{|c|c|c|c|c|c|c|c|c|c|c|c|c|}
8 & & & & & & & & 250 & 7250 & 19250 & 40250 & 72250 \\
\hline 9 & & & & & & & & & 250 & 6250 & 20250 & 44250 \\
\hline 1 & & & & & & & & & & & & \\
0 & & & & & & & & & & 250 & 7250 & 23250 \\
\hline 1 \\
1
\end{tabular}

Based on the calculation of the Minimum Cost $\left(f_{n}\right)$ in a second step Wagner-Within algorithm methods can be found in Appendix 2. The calculation of the minimum cost at 12 this period based on the assumption of inventory at the end of the period is zero. In this step is done by adding the total variable costs at a minimum cost in the previous period. The value of the minimum cost is calculated backwards by finding the minimum cost of each column. In Appendix 3, shows that the minimum charge obtained in each column sequentially meet on the same line period.

Appendix 2 Minimum Cost Value Calculation Table USD (.000)

\begin{tabular}{|c|c|c|c|c|c|c|c|c|c|c|c|c|c|}
\hline \multicolumn{14}{|c|}{ Demand } \\
\hline \multirow{14}{*}{ 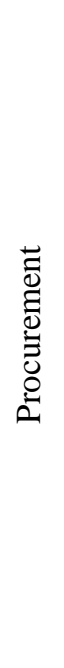 } & & 1 & 2 & 3 & 4 & 5 & 6 & 7 & 8 & 9 & 10 & 11 & 12 \\
\hline & 1 & 250 & 6250 & 22250 & 37250 & 65250 & 95250 & 137250 & 193250 & 249250 & 303250 & 373250 & 461250 \\
\hline & 2 & & 500 & 8500 & 18500 & 39500 & 63500 & 98500 & 146500 & 195500 & 243500 & 306500 & 386500 \\
\hline & 3 & & & 750 & 5750 & 19750 & 37750 & 65750 & 105750 & 147750 & 189750 & 245750 & 317750 \\
\hline & 4 & & & & 1000 & 8000 & 20000 & 41000 & 73000 & 108000 & 144000 & 193000 & 257000 \\
\hline & 5 & & & & & 1250 & 7250 & 21250 & 45250 & 73250 & 103250 & 145250 & 201250 \\
\hline & 6 & & & & & & 1500 & 8500 & 24500 & 45500 & 69500 & 104500 & 152500 \\
\hline & 7 & & & & & & & 1750 & 9750 & 23750 & 41750 & 69750 & 109750 \\
\hline & 8 & & & & & & & & 2000 & 9000 & 21000 & 42000 & 74000 \\
\hline & 9 & & & & & & & & & 2250 & 8250 & 22250 & 46250 \\
\hline & 10 & & & & & & & & & & 2500 & 9500 & 25500 \\
\hline & 11 & & & & & & & & & & & 2750 & 10750 \\
\hline & 12 & & & & & & & & & & & & 3000 \\
\hline & $f^{*}$ & 250 & 500 & 750 & 1000 & 1250 & 1500 & 1750 & 2000 & 2250 & 2500 & 2750 & 3000 \\
\hline
\end{tabular}

Based on the calculation in the first and second steps, then do is interpret the minimum charge into the lot size order. This method will minimize the amount of inventory in the company, this happens because this VGL argon gas cylinders ordered upon request in the period. The total cost of inventory is calculated Wagner-Within algorithm is $\mathrm{Rp} 691.5$ million. In these calculations is found by adding the cost of purchasing the booking fee, as well as storage costs per period. Storage costs are assumed to Rp 0, for each Gas Argon purchased VGL will once discharged on the period. Calculation of the total cost of this is done per period, this is because the lot size and the booking period obtained after calculation algorithm Wagner-Within is a demand in the period.

Wagner-Within algorithm method selected as the appropriate method for VGL Argon Gas supply planning this, because basically this method can provide the optimum solution for the problem of dynamic booking lot deterministic. The number of times different booking will certainly affect the number of VGL Argon Gas supplies were stored, so it will affect the amount of fees and storage costs. Wagner-Within algorithm is used to supply the optimum by minimizing the total cost of ordering and storage costs, where the calculation is done testing all the way of ordering to meet the net requirements in each period which is in the planning horizon. Determination of inventory management strategy is based on booking data in the previous period. This method uses dynamic programming approach, ie a model mathematics to get the optimum solution.

Determining the frequency of booking is also important to note, because it will affect the amount of the booking fee. This will affect the decision-making what amount to be booked to meet the needs of Argon Gas VGL to avoid depleted stock. Inventories also have a major impact on the cost of storage. If the VGL Argon Gas supply is not sufficient, it will certainly affect the process of laboratory testing to pose risks, such as laboratory testing process that is inhibited so that the released product will be delayed. Besides the need for emergency procurement costs. Whereas, if the argon gas supply VGL excess (over stock), this affects the risk of high costs for storage in a warehouse.

The total cost Argon Gas supply VGL with EOQ model of Rp 694.875 million. The total cost of this inventory is derived from aggregating the cost of purchase, cost of ordering and storage costs. The difference between the total cost of inventory EOQ Algorithm Wagner-Within Rp 3.375 million. This suggests that the Wagner-Within algorithm method is the right solution to solve the problems of supply of dynamic deterministic models on Argon Gas VGL at PT ABC. 


\section{CONCLUSION}

Based on the results of data processing and analysis in the previous chapter, it can be concluded as follows:

1. Total Gas Argon purchased and stored VGL is in accordance with the number of requests on a per period, Argon Gas procurement time VGL done regularly per period, this is due to the use of this VGL Argon gas once discharged in one period and no storage costs.

2. The total cost of inventory Wagner-Within algorithm for Rp691.500.000. This cost is obtained from the calculation of the total cost per period based upon the lot size and the time of reservation obtained from Wagner-Within algorithm calculation, while the total cost of inventory EOQ Rp 694.875 million. This suggests that the Wagner-Within algorithm to minimize total inventory cost Rp 3.375 million

\section{SUGGESTION}

Argon Gas inventory control VGL in PT ABC suggested to use Wagner-Within algorithm method, because this method according to the company's condition precisely on materials that have erratic ordering frequency in each period

\section{REFERENCES}

1. Assauri, S. 2008. Production and Operations Management. Revised Edition. Jakarta: Issuing Faculty of Economics, University of Indonesia.

2. Happy, SN 2006. Inventory System. Bandung: ITB Publishers

3. Basuki. Booking 2016. Lot Size Optimization Economical on Dynamic Deterministic Demand Wagner Within Algorithm Using [Journal]. Bekasi (ID): Palm Citra Widya Polytechnic Education. Vol.5 (1) Page 29-34

4. Chandradevi, A., \& Puspitasari, NB, 2016. Application of Material Requirement Planning (MRP) with Consider Lot Sizing in Raw Material Control at PT. Phapros, Tbk.PERFORMANCE: Media Scientific Industrial Engineering, Vol 15 (1) Page 77-86

5. Gaspersz, V. 2004. Production Planning and Inventory Control (PPIC) Pendekan Based Integrated Systems MRP II and JIT Manufakturig 21. Towards Jakarta: Gramedia Utama

6. Gitosudarmo, I. 2002. 4. Financial Management Edition Yogyakarta: BPFE

7. Haming, M and N. 2014. Mahfud Modern Production Management: Manufacturing and Service Operations Book 2. Jakarta: Earth Literacy.

8. Heizer, J., \& Render, B. 2010. Operation Management (7th ed). Jakarta: Four Salemba.

9. Kumar, R. 2016. Economic Order Quantity (EOQ) model.Global Journal of finance and economic management Vol 5 (1), 1-5.

10. Lutfi, W., Santoso, EB, \& Paramita, PD 2018. Analysis of Raw Material Inventory Control Method Using Economic Order Quantity (EOQ) To Achieve Smooth Production (Case Study at CV. Cynthia Holy Box). Journal Of Accounting 2018, Page 1-.10

11. Lwiki, Timothy. et al. 2013. The Impact of Inventory Management Practices on Financial Performance of Sugar Manufacturing Firms in Kenya. International Journal of Business, Humanities and Technology Vol.3 (5). It 75-85

12. Mazdeh, MM, Emadikhiav, M., \& Parsa, I. 2015. A heuristic to solve the dynamic lot sizing problem with supplier selection and quantity Discounts. Computers \& Industrial Engineering, Vol 85, Page 33-43.

13. Nasution, Arman H., \& Yudha P. 2008. Production Control Planning. First Edition. Yogyakarta: Graha Science

14. Pardede, PM 2007. Operations and Production Management: Theory, Models and Policy. Revised Edition. Yogyakarta: Andi

15. Poirier, L., Nelson, J., Leong, D., Berhane, L., Hajdu, P., \& Lopez-Linares, F. 2016. Application of ICP-MS and ICPOES on the determination of nickel, vanadium, iron, and calcium in petroleum crude oils via direct dilution. Energy \& Fuels, 30 (5), Page 3783-3790.

16. Ramadhanti, LC, \& Ariyanti S. 2017. Analysis of Material Requirements Planning Study J100 Bold \& Nuts At PT. Pertamina Hulu Energi ONWJ. SURE: Mercu Buana Engineering Journal, Vol 11.(3), Page 283-299

17. Rangkuti, F., 2004. Inventory Management Applications in the Business Sector. Jakarta: Erland.

18. Rahim, T., \& Saroso, DS 2017 Booking Quantity Economical Analysis and Production Systems at Process Timely Care Heavy Equipment PT. Harita Nickel.Synergy: Journal of Engineering Mercu Buana, Vol 21 (2), Page 129-140.

19. Ristono, A. 2013. Inventory Management. Yogyakarta: Graha Science

20. Shen, H., Deng, Q., Lao, R., \& Wu, S. 2016. A case study of inventory management in a manufacturing company in China.Nang Yan Business JournalVol 5 (1), Page 20-40

21. Selih, VS, Sala, M., \& Drgan, V. 2014. Multi-element analysis of wines by ICP-MS and ICP-OES and their classification According to geographical origin in Slovenia.food Chemistry, 153, Page 414-423. 